Hardianto Rahman, Syamsul Bachri Thalib, Alimuddin Mahmud

Indonesia

\title{
Integrated Character Education in Social Sciences with Contextual Teaching and Learning Approach
}

DOI: 10.15804/tner.2017.48.2.04

\begin{abstract}
The presented study aims at increasing positive attitude of students as good citizens through the integration of character education in social studies with CTL approach. This research was classroom action research and the subjects of this research were 38 fifth-grade pupils of Elementary School SD Negeri 07 Panreng Sinjai. The study involved collaborators that were fifth-grade teachers who acted as the implementing action. Data were obtained through a test scale of attitude as the main data and supporting data were collected through observation and self-report. The research showed some findings. First, the integration of character education in teaching social studies is conducted by instilling the values of character education in learning with the social studies content and applying some of the components in the CTL. Second, there is continuous improvement of the integration of character education in social studies with the CTL approach from the first cycle to the third cycle. Based on the results of attitude tests on the citizenship subject in the first cycle, there was no student classified as very positive ( $0 \%), 44.73 \%$ of students were classified as positive, $39.47 \%$ negative, and $15.76 \%$ very negative. In the second cycle, there were $23.68 \%$ of students classified as very positive, $44.73 \%$ positive, $26.31 \%$ negative, and $5.26 \%$ very negative. In the third cycle, there were $18.42 \%$ of students classified as very positive, $78.94 \%$ positive, $2.63 \%$ negative and $0 \%$ very negative. Thus, the integrated character education in social studies can improve the attitude of a good citizen in fifth- grade pupils of SD Negeri 07 Panreng Sinjai.
\end{abstract}

Keywords: character education, social sciences, contextual teaching 


\section{Introduction}

Formal education is a path of education in school, and informal education is the path of education in the family environment and surrounding communities. Moral development of children at the primary school age should be considered by parents and teachers at school. Santrock (2004) claims that "Moral development involves the development of thoughts, feelings, and behaviors regarding rules and conventions about what people should do in their interaction with other people". Therefore, education in school plays a very important role in shaping students' attitudes, behavior, and character. Thus, school is an effective vehicle for internalization of students' character.

Character education is a solution in shaping and improving the morals of every nation. It is in line with the opinion expressed by Prestwich (2004) that "...the rise in violent crime and a general feeling by the public that American children suffered a crisis in morals led to a resurgence of character education programs across the nation...."

Correspondingly, based on conceptual analysis and learning conditions in fifth grade at SD Negeri 07 Panreng Sinjai, who serve as research subjects, there were several findings. First, the students' response to social studies is still low. The indicators that can be seen from the results of the initial observation show that students' attention and involvement are still low and the attitudes and behavior of students are also lacking. Second, learning is still teacher-centered. Based on the observation results, the teacher still delivers material derived from the textbook. Students pay little attention and they do not get an opportunity to express their opinions. Teachers are transmitters of the material and students as recipients. Third, there is little variation in teachers' teaching methods. While delivering the subject matter, teachers only use the lecturing method without regarding the approach of learning methods. Fourth, learning approaches such as CTL, cooperative learning $(\mathrm{CL})$, and the latest approaches are never used due to learning difficulties and time. Fifth, teachers have not yet integrated social studies with other disciplines, so there is more emphasis on the mastery of social science teaching materials. Thus, the development of students' citizen attitudes as part of the purpose of social sciences is still lacking. Sixth, students' attitude and behavior are less controlled, which means that students have not shown a great attitude.

In relation to the above-mentioned problems, the efforts to improve the quality of learning and character development of students as good citizens in social science learning is an essential thing that needs to be considered. One thing that can be done by teachers and schools is the integration of character education with 
a contextual approach. Especially in social studies, the thing that needs to be done by the teacher is integrating some aspects such as moral values, humanity, democracy, nationality, and other values that are deemed relevant to the improvement of students' character as good citizens.

Character education is one of the efforts in shaping holistic character, which is developing the physical, emotional, social, creative, spiritual, and intellectual aspects of students optimally. The character development of students, according to Lickona (1991), can be achieved through the stages of knowing, acting, and habits.

Otten (2000) states that "Character education is an umbrella term used to describe many aspects of teaching and learning for personal development," whereas Elkind and Sweet (2004) define "character education as the deliberate effort to help people understand, care about, and act upon core ethical values."

Character education integrated into social science learning is relevant since social science competence concerns students' solving problems in their environment. Social studies according to the National Council for Social Studies (NCSS), as quoted in the book entitled Elementary Social Studies:

"Social studies is the integrated study of social sciences and humanities to promote civic competence. Within the school program, social studies provide coordinated, systematic study drawing upon such disciplines as anthropology, archeology, economics, geography, history, law, philosophy, political science, psychology, religion, and sociology, as well as appropriate content from the humanities, mathematics, and natural sciences" (Savage, Armstrong, \& Potthoff, 2000).

Through social studies lessons, students will be directed, guided and trained to become good citizens of the world. The purpose of education and social studies is that the student becomes a citizen of the world. It can also develop the ability to think to understand, respond, adapt, and solve social problems. Moreover, it can understand, remember, and continue the culture of the nation. Thus, students are expected to have the sensitivity and ability to understand, study and participate in solving the problems of social and nationality, as well as inheriting and developing the noble values of the nation's culture. There are several indicators of the learners who are regarded as good citizens of the world. They are faithful and devoted to God Almighty with their spiritual intelligence, and they are loyal to the basic philosophy and the state ideology of Pancasila. They are disciplined to obey all laws and norms in force. They fulfill their obligations as citizens. They respect and can work together with members of their own and other nations. They develop a sense of unity and oneness. They are fair, responsible, democratic, and tolerant. In addition, they understand the feelings of all citizens, religious and cultural nation, to exercise their rights appropriately and proportionately. 
To make learning more meaningful, an integrated character education in social sciences needs to be realized by using the method of Contextual Teaching and Learning (CTL). CTL is a concept that helps teachers to associate the learning material with the students' real-world situations and encourage students to make connections between knowledge possessed by its application and their daily lives. Johnson (2002) defines CTL as follows:

"The CTL system is an educational process that aims to help students see meaning in the academic material they are studying by connecting academic subjects with the context of their daily lives, that is, in the context of their personal, social, and cultural circumstances. To achieve this aim, the system encompasses the following eight components: making meaningful connections, doing significant work, self-regulated learning, collaboration, critical and creative thinking, nurturing the individual, reaching high standards, using authentic assessment".

Based on these definitions, CTL is considered a comprehensive system. CTL consists of some parts that are connected with each other. If these parts are associated with each other, they will produce the effect that exceeds a given outcome of its parts separately.

According to (Johnson, 2002), the CTL system includes eight components, namely:

1. Creating meaningful linkages

2. Doing meaningful work

3. Performing self-regulated learning

4. Cooperating

5. Doing critical and creative thinking

6. Helping individuals to grow and thrive

7. Achieving high standards

8. Using authentic assessment

There are three scientific principles in CTL mentioned by Johnson (2002), namely: (1) the principle of interrelatedness, (2) the principle of differentiation, and (3) the principle of self-regulation. Various scientific studies thoroughly and accurately pinpointing the entire universe are sustained and governed by three above-mentioned principles (Johnson, 2002).

Based on the above, the presented research focuses on the issue of social studies lesson in the $5^{\text {th }}$ grade of SD Negeri 07 Panreng Sinjai. This subject has not been integrated into other disciplines, and has not applied the CTL approach entirely. Thus, the research is focused on developing students' positive attitudes through the integration of the values of character education in social studies with the use 
of the CTL approach. With the CTL approach, students are expected to get a deep understanding, which can be applied when dealing with new situations in society.

\section{Research methodology}

The study was classroom action research (CAR) focused on the classroom situation. CAR is one of the research types that teachers do to improve the quality of learning in the classroom. The design of this classroom action research is a spiral or cycle model proposed by Kemmis, McTaggart, and Nixon (2013), with the following steps:

Figure 1. Spiral Model of Action Research proposed by Kemmis and Taggart

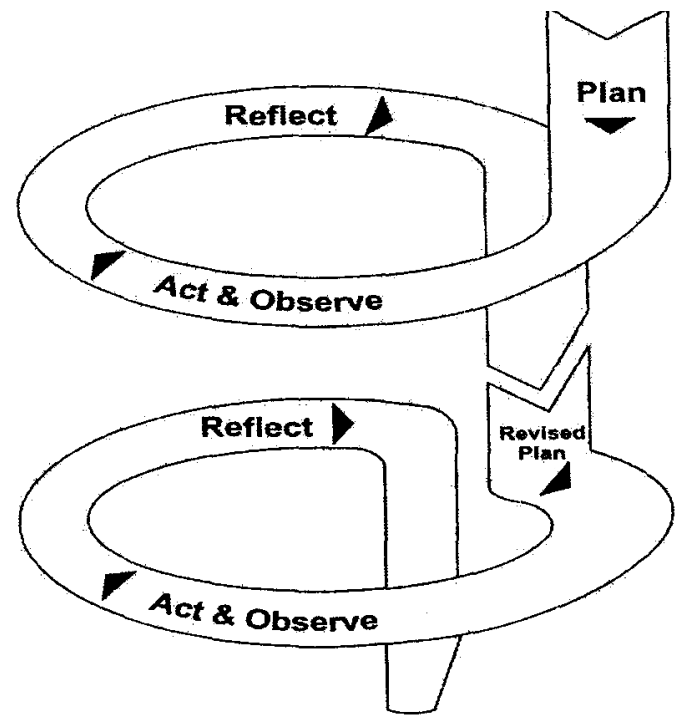

The type of action taken in the development of the student's character as a good citizen is by integrating character education in social studies with the CTL approach. The success of this research is characterized by changes for the better, both related to students' activities during the learning process and learning outcomes in social studies in particular changes in student behavior. The criteria are as follows:

1. To give meaning to the learning process after the implementation of CTL, a criterion was used by comparing the activity of students in the action / 
first cycle to the next cycle. If students' attitude after participating in learning activities is better than before the procedure, it can be said that the action was successful.

2. Giving meaning to the successful implementation of the action is based on the development of attitude and student learning outcomes, which can be seen from the achievement test scores according to the subject matter provided.

The study was conducted from March to May 2016 with 38 fifth-grade students of Elementary School 07 Panreng, Sinjai regency. The subjects were selected with the use of purposive sampling with some primary considerations. The fifth-grade students of the school have the heterogeneous ability and have an unfavorable attitude or character compared to other grades. Data were collected using some techniques, namely observation, attitude test, questionnaire, interview, analysis of documents and field notes.

1. The observation technique was used to obtain data or information about activities in the classroom. Learning activity was observed using an observation sheet. An observation sheet is an instrument used to observe adherence to aspects of good citizenship of students during learning activities. Assessment is done by attributing + (positive) to students' positive behavior and - (negative) to students' negative behavior. The success of an action is indicated by an increase in the percentage / number of students who received A of the + (positive) sign and a decrease in the percentage of students to obtain A - (negative) sign. In addition, the blank sign means that the student did not show striking behavior.

2. The attitudes test was used to explore student responses toward the aspects of the character of a good citizen related to learning the materials which were studied. The test results are grouped in two sections based on Guttman's scale, namely agree and disagree. They are then classified according to the categorization of the student's attitude, as shown in the table below:

Table 1. Categorization of students' attitude

\begin{tabular}{cll}
\hline No & \multicolumn{1}{c}{ Students' Score } & \multicolumn{1}{c}{ Categories } \\
\hline 1 & $\mathrm{X} \geq \mathrm{x}+1 . \mathrm{SBx}$ & Very Positive \\
\hline 2 & $\mathrm{x}+1 . \mathrm{SBx}>\mathrm{X} \geq \mathrm{x}$ & Positive \\
\hline 3 & $\mathrm{x}>\mathrm{X} \geq \mathrm{x}-1 . \mathrm{SBx}$ & Negative \\
\hline 4 & $\mathrm{X}<\mathrm{x}-1 . \mathrm{SBx}$ & Very Negative \\
\hline
\end{tabular}


3. The personal report is where the students were asked to make reviews unbiased view or a comment about an issue, situation, or thing which is the object of attitude. Based on the reviews made by students, their underlying sentiment can be read and understood.

\section{Results}

The researchers encountered some obstacles and weaknesses in the implementation of learning with the integration of character education and the CTL approach in the first cycle. The conditions show that the fifth-grade students of elementary school 07 Panreng still need a lot of guidance. They also need a concrete example of the wide range of activities and methods of the learning model. In addition, the teachers themselves still have much to learn. However, in general, the students had high motivation and passion because the learning is interspersed with various fun methods.

Based on the results of the test of the citizenship attitude of the students in the first cycle, it can be seen that among 38 students, no student obtained a very positive result ( $0 \%), 17$ students obtained a positive result (44.73\%), 15 students obtained a negative result (39.47\%), and 6 students obtained a strongly negative result (15.76\%). The results can be seen in the histogram below:

Figure 2. Histogram scale of the student attitudes in the first cycle

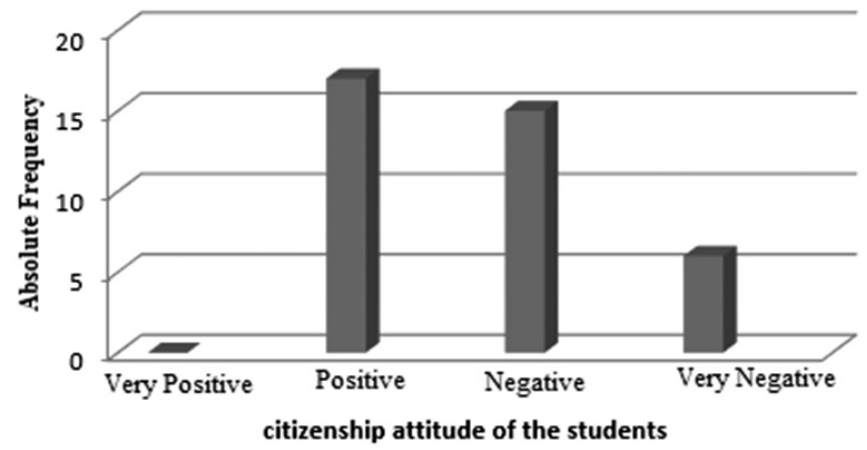

Based on the results of the students' observations sheet about some aspects of the attitude in the learning process, five students show good behavior (13.1\%), 22 students are less good (57.8\%), and 11 students are normal (28.9\%). Based on 
the results of the students' personal statements about good citizens, there were 16 students who answered correctly in accordance with the indicators (42.1\%), and 22 less correctly (57.8\%). Thus, in the first cycle, the students' citizenship attitudes were not satisfactory.

In the second cycle, classroom action runs more smoothly. The teachers' readiness is steadier in teaching, thus the flow of teaching given to students seems clear and coherent. The students are more interested, brave, and confident in teaching and learning activities. The implementation of the integration of character education in social studies with the CTL approach started smoothly. The weaknesses in the first cycle can be minimized and repaired and even enhanced.

In the second cycle, there was an improvement compared to the first reporting period, which is based on test results from 38 students. There were nine students whose responses were very positive (23.68\%), 17 students gave a positive response (44.73\%), ten students gave a negative response (26.31\%), and two students gave a very negative response (5.26\%). The results are presented in Figure 3:

Figure 3. Histogram scale of student attitudes in the second cycle

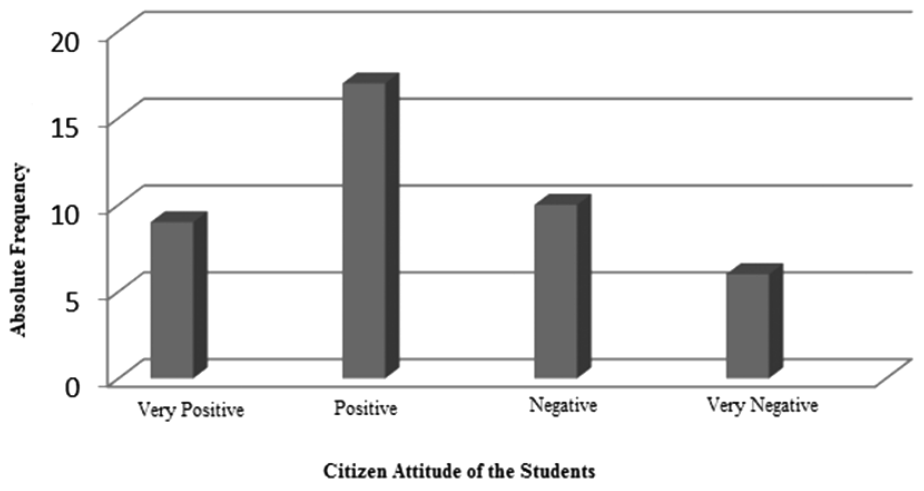

Based on the observation sheet concerning some aspects of the learning process, 13 students demonstrated good behavior (34.2\%), ten students showed less good behavior (26.3\%) and 15 students showed normal behavior (39.4\%).

Based on the results of the students' personal statements about good citizens, out of the 38 students, there were 24 people (63.1\%) who answered correctly in accordance with the indicators, and 14 (36.8\%) who gave a less correct answer Thus, the development of the students' citizen attitudes started to appear in the second cycle. 
The implementation of the integration of character education in social studies learning with the CTL approach in the third cycle ran smoothly and was much better than the two previous cycles. It was the result of the improvements made by the researchers based on the weaknesses in the first cycle and the second cycle and they became capital to the implementation of the third cycle, from planning, implementation, and evaluation.

The attitude tests showed the improvements of the two previous cycles, i.e., out of the 38 students, seven students gave very positive answers (18.42\%), 30 students gave positive responses (78.94\%), 1 student gave a negative response (2.63\%), and there was no student who gave very negative response $(0 \%)$. The results are shown in the histogram below:

Figure 4. Histogram scale of student attitudes in the third cycle

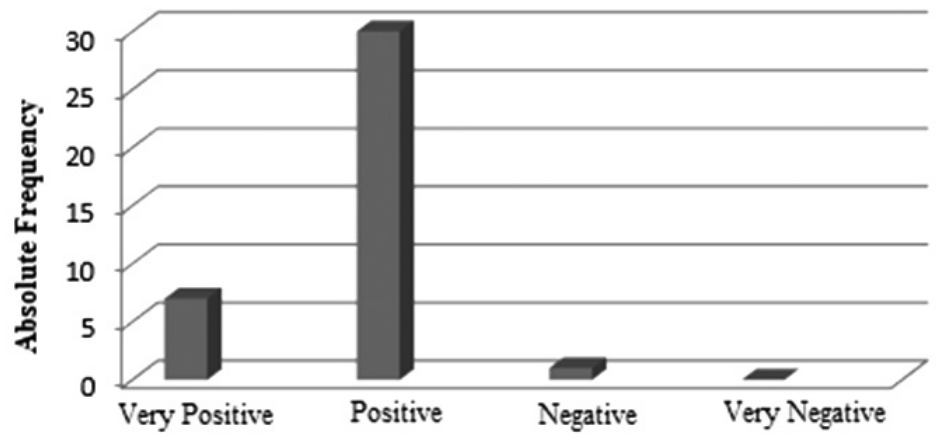

Citizen Attitude of the Students

Moreover, based on the students' observation sheets concerning some aspects of the learning process, there was also a significant increase compared with the previous two cycles. Out of the 38 students, 20 showed good behavior (52.6\%), 3 showed less good behavior (7.8\%), and 15 showed normal behavior (39.4\%). Likewise, the reports from the students' personal statements about some of the good citizens significantly increased compared with the two previous cycles, i.e., out of the 38 students, 31 answered correctly in accordance with the indicators (81.5\%), and seven answered incorrectly (8.4\%). The responses at the end of each cycle always increased. It is shown in the following Table 2.

The comparison of the student attitudes in each cycle can also be seen in the following Figure 5. 
Table 2. Comparison of the percentages of the Citizenship Attitude Scale of the students: Cycles I, II, III

\begin{tabular}{ccccc}
\hline Cycle & Very Positive & Positive & Negative & Very Negative \\
\hline I & $0 \%$ & $44.73 \%$ & $39.47 \%$ & $15.76 \%$ \\
\hline II & $23.68 \%$ & $44.73 \%$ & $26.31 \%$ & $5.26 \%$ \\
\hline III & $18.42 \%$ & $78.94 \%$ & $2.63 \%$ & $0 \%$ \\
\hline
\end{tabular}

Figure 5. Student attitudes in each cycle

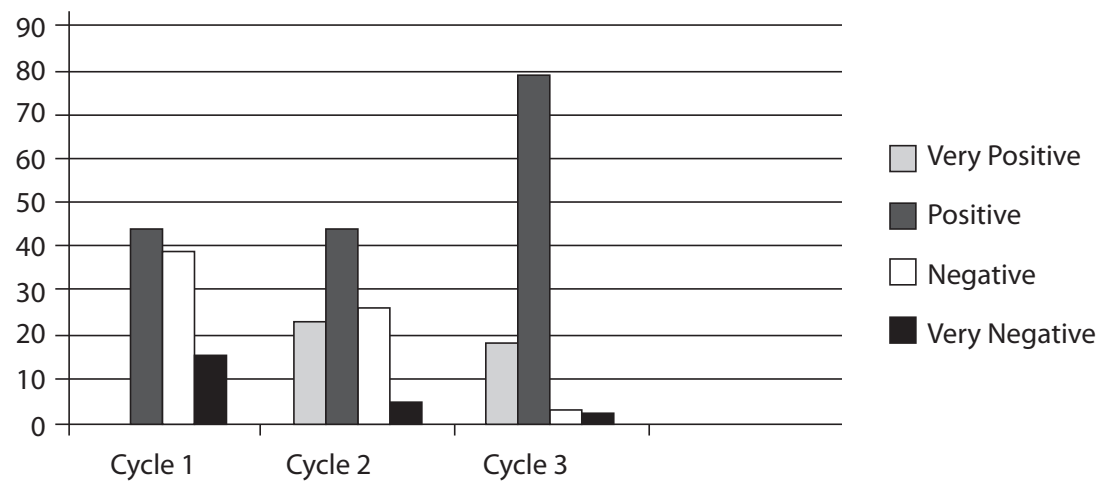

\section{Discussion}

The process of integration of character education in teaching social studies is conducted by instilling the values of character education in students. Those values are the values of Pancasila included in grains P-4 adjusted to the content of the subject matter. Learning is also done by applying some of the components in CTL and always contextualizes or connects learning to everyday life. Therefore, students find learning more meaningful. The result can increase positive attitudes as good citizens and students are more motivated to learn due to the creation of a pleasant atmosphere. Teachers play a very important role in creating this situation as indicated by Henderson (1947, p. 144): "we can find the basis for morality in our own natures, in the conduct necessary to realize our best potentialities and the kind of society in which man could live as man". In the Contextual Teaching and Learning approach, the integration of character education in social studies can connect what students learn with how they use it in the real world.

The results of this study also confirm the research conducted by Berkowitz (2011), in which the results showed an increase in the motivation of the students in 
academic achievement in schools that implement character education. The classes which are comprehensively engaged in character education show drastic decline in the negative behavior of students that can hinder their academic success.

This study also demonstrates the integration of cognitive, affective and psychomotor domains so that inclusion of noble values in social studies can be realized. Thus, it is possible to develop an attitude of citizenship in students for them to become better. At the end of the lesson students can find the real meaning of social studies. Therefore, this method can suppress a decrease in civic attitude, especially in the research object.

\section{Conclusion}

Some conclusions can be drawn. First, efforts to improve the good citizen attitude in the fifth-grade students of SD Negeri 07 Panreng Sinjai District can be realized through the integration of character education in social studies with the CTL approach. The process of character education is integrated in the learning of social studies conducted by including the values of character education in learning tailored to the content of the subject matter. Learning is also conducted by applying some of the components of CTL and always contextuatizing or connecting learning with everyday life, so that students can find learning more meaningful. The process of integration of character education into social studies with the CTL approach makes the interactions between students and students and teachers more intensive and in turn it creates a fun and meaningful environment. Second, the improvement of a good citizen attitude in social studies through the integration of character education with the CTL approach in SD Negeri 07 Panreng Sinjai can be shown through the results of attitude scale tests in each cycle, which are increased continuously from cycle I, to cycle II, to cycle III.

\section{References}

Berkowitz, M.W. (2011). Understanding effective character education. The Literacy and Numeracy Secretariat Capacity Building Series: Expert Perspectives. Retrieved from http://www.character.org/wp-content/uploads/2011/12/Understanding-Effective-Character-Education.pdf

Elkind, D.H., \& Sweet, F. (2004). How to do character education. Artikel Yang Diterbitkan Pada Bulan September/Oktober. 
Henderson, S. (1947). Introduction to philosophy of education. Retrieved from https:// philpapers.org/rec/HENITP-3

Johnson, E.B. (2002a). Contextual teaching and learning: What it is and why it's here to stay. Corwin Press.

Johnson, E.B. (2002b). Contextual teaching and learning: What it is and why it's here to stay. Corwin Press.

Kemmis, S., McTaggart, R., \& Nixon, R. (2013). The action research planner: Doing critical participatory action research. Springer Science \& Business Media.

Lickona, T. (1991). Educating for character (New York, Bantam). McCI ET nAN, BE (1992) Schools and the Shaping of Character: Moral Education in America, 525-543.

Otten, E.H. (2000). Character Education. ERIC Digest.

Prestwich, D.L. (2004). Character education in America's schools. School Community Journal, 14(1), 139.

Santrock, J.W. (2004). Educational psychology, University of Texas at Dallas.

Savage, T.V., Armstrong, D.G., \& Potthoff, B.J. (2000). Effective teaching in elementary social studies. Merrill. 